\title{
Caracterização de argilas da Depressão do Piraí e da Bacia de Curitiba (PR)
}

\author{
Mário Sérgio de Melo ${ }^{1}$, Thiago Felipe Schier de Melo ${ }^{2}$, Adriana Scoton Antonio Chinelatto ${ }^{1}$, \\ Adilson Luiz Chinelatto ${ }^{1}$, Luiz Alberto Fernandes ${ }^{3}$ \& Gilson Burigo Guimarães ${ }^{1}$
}

\begin{abstract}
Resumo A Depressão do Piraí e a Bacia de Curitiba, situadas no Primeiro Planalto Paranaense, são áreas de ocorrência de sedimentos predominantemente argilosos acumulados em espaços criados por blocos de falhas rebaixados durante o Cenozóico. São áreas pouco estudadas, incluídas no Sistema de Riftes Cenozóicos do Sudeste do Brasil. Até recentemente não se conheciam adequadamente as características e extensão das litofácies e tampouco as propriedades tecnológicas das argilas destas áreas. Este trabalho objetivou estudar as características físicas, químicas e morfológicas de amostras de sedimentos argilosos destas duas áreas. A metodologia utilizada compreendeu caracterização química e mineralógica (microscopia eletrônica de varredura, espectrometria de energia dispersiva, difratometria e fluorescência de raios $\mathrm{X}$, análise térmica diferencial, análise termogravimétrica) e caracterização tecnológica (sinterização, retração linear, perda ao fogo, massa específica e porosidade aparente, absorção de água, módulo de resistência à flexão mecânica). Os resultados indicam a presença predominante de caulinita tanto detrítica quanto diagenética nas duas depressões estudadas. $\mathrm{Na}$ Bacia de Curitiba ocorrem também esmectita e ilita de aspecto diagenético. As propriedades tecnológicas determinadas indicam a possibilidade de utilização desses materiais em produtos de cerâmica vermelha e alguns para a produção de pisos.
\end{abstract}

Palavras-chave: Sedimentos argilosos, caracterização tecnológica de argilas, cerâmica, Bacia de Curitiba, Depressão do Piraí, Formação Guabirotuba.

\begin{abstract}
Characterization of clays from the Pirai Trough and the Curitiba Basin, State of Paraná. The Piraí Trough and the Curitiba Basin, situated in the First Paraná Plateau, are two areas of occurrence of clayey sediments accumulated during the Cenozoic in lowered faulted blocks. Both areas are little studied, the Curitiba Basin is included in the System of Cenozoic Rifts of Southeastern Brazil, the deposits of the Piraí Trough are still less known. Until recently characteristics and extension of lithofacies were not adequately known and neither the technological properties of the clayey sediments. This research aimed to study physical, chemical and morphologic characteristics of clays from these two areas. Methods included chemical and mineralogical characterization (scanning electron microscopy, energy dispersive spectrometry, X-ray diffractommetry, X-ray fluorescence, differential thermal analysis, thermogravimetric analysis) and technological characterization (sintering process, linear shrinkage, loss on ignition, apparent specific gravity, apparent porosity, water absorption, flexural resistance). The results indicate kaolinite predominance so much detrital how much diagenetic in the two studied depressions. In the Curitiba Basin occur also diagenetic smectite and illite. The technological properties indicate certain of the studied materials can be used in bricks and tiles.
\end{abstract}

Keywords: clayey sediments, technological properties of clays, ceramics, Curitiba Basin, Piraí Trough, Guabirotuba Formation.

INTRODUÇÃO A Depressão do Piraí, localizada entre as cidades de Castro e Piraí do Sul, e a Bacia de Curitiba, localizada na região metropolitana da capital paranaense (Fig. 1), são duas áreas de ocorrência de sedimentos em grande parte argilosos, acumulados e parcialmente preservados graças a rebaixamentos e basculamentos de blocos de falhas durante o Cenozóico. Na Depressão do Piraí predominam sedimentos de origem gravitacional derivados das rochas do Grupo Castro e do Complexo Granítico Cunhaporanga. Na Bacia de Curitiba os sedimentos argilosos pertencem à Formação Guabirotuba, sendo derivados de granitos, gnaisses e rochas metamórficas do Grupo Açungui.

As duas áreas em estudo têm suas origens no contexto evolutivo das bacias do Sistema de Riftes Cenozóicos do Sudeste do Brasil, desenvolvidas a partir do Paleógeno até o Quaternário. Situam-se no denominado Primeiro Planalto Paranaense e distam, respectivamente, cerca de 150 e $40 \mathrm{~km}$ do pólo cerâmico de Campo Largo, situado na Região Metropolitana de Curitiba.

Contexto geológico regional: O Sistema de Riftes Cenozóicos do Sudeste do Brasil O Sistema de Riftes Cenozóicos do Sudeste do Brasil (SRCSB), ex-

1 - UEPG, Ponta Grossa (PR), Brasil. E-mail: msmelo@uepg.br, adrianachinelatto@gmail.com, adilson@uepg.br, gburigo@ig.com.br

2 - UEPG, Programa de Pós-Graduação em Geografia, Ponta Grossa (PR), Brasil. E-mail: Thigo_geo@hotmail.com.br

3 - UFPR, Curitiba (PR), Brasil. E-mail: lufernandes@ufpr.br 


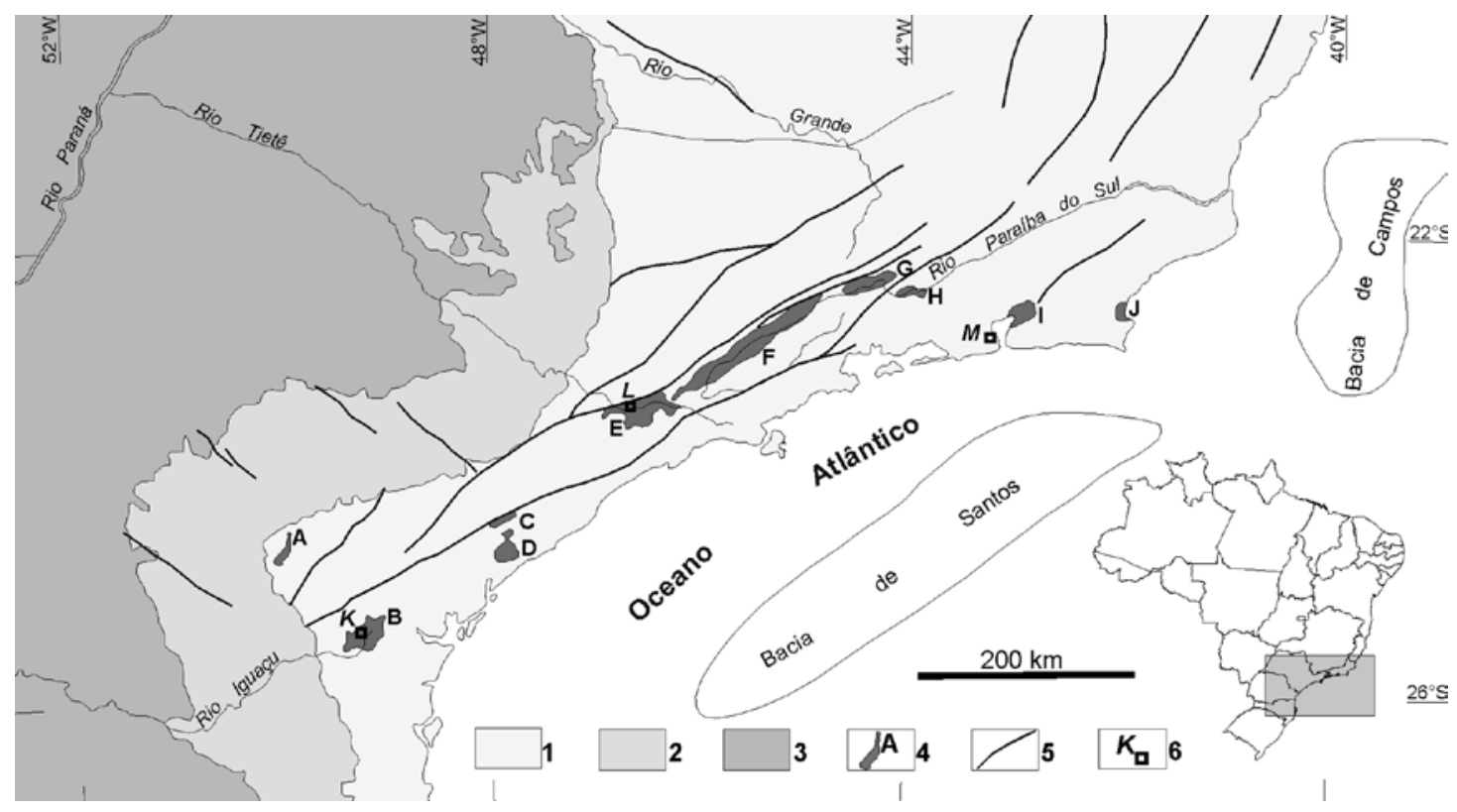

Figura 1- Localização da Depressão do Piraí e da Bacia de Curitiba no Sistema de Riftes Cenozóicos do Sudeste do Brasil. 1) embasamento pré-cambriano; 2) rochas sedimentares paleozóicas e mesozóicas da Bacia do Paraná; 3) derrames da Formação Serra Geral e coberturas cretáceas; 4) principais bacias sedimentares cenozóicas: A) Depressão do Piraí; B) Bacia de Curitiba; C) Gráben de Sete Barras; D) Formação Pariqüera-Açu; E) Bacia de São Paulo; F) Bacia de Taubaté; G) Bacia de Resende; H) Bacia de Volta Redonda; I) Formação Macacu (Gráben da Guanabara); J) Gráben de São João; 5) falhas principais; 6) cidades principais: K) Curitiba; L) São Paulo; M) Rio de Janeiro (baseado em Melo et al. 1985, Riccomini et al. 2004, Zalán \& Oliveira 2005).

pressão utilizada por Zalán \& Oliveira (2005) para o antes denominado Sistema de Riftes da Serra do Mar (Almeida 1976), Sistema de Bacias Tafrogênicas Continentais do Sudeste do Brasil (Melo et al. 1985) ou ainda Rifte Continental do Sudeste do Brasil (Riccomini 1989), compreende um conjunto de blocos de falha que se estende da região litorânea à plataforma continental adjacente das regiões sul e sudeste do Brasil. Os deslocamentos ao longo destas falhas durante o Cenozóico geraram depressões e altos estruturais que se estendem por faixa alongada na direção ENE-WSW por mais de 900 km, desde a Região Metropolitana de Curitiba (PR) até Macaé (RJ).

Zalán \& Oliveira (2005) identificaram quatro riftes principais no sistema: Paraíba do Sul, que inclui as bacias de São Paulo, Taubaté, Resende e Volta Redonda; Ribeira, que inclui os grábens de Sete Barras e do Alto Ribeira; Litorâneo, que inclui os grábens de São João, da Guanabara (Formação Macacu e outras associadas), de Cananéia e Paranaguá; e Marítimo, que inclui depressões situadas na plataforma continental.

A Depressão do Piraí, estudada por Lima \& Melo (inédito) e Lima (inédito), localiza-se no Gráben do Alto Ribeira de Zalán \& Oliveira (2005). Os depósitos cenozóicos da área têm sido mencionados desde longa data (Almeida 1952, Coutinho 1955), mas o detalhamento da caracterização do sítio deposicional e da faciologia ainda carecem de divulgação mais abrangente. Os estudos realizados indicam que a depressão está relacionada com os mesmos fenômenos geológicos regionais ligados à evolução do sistema de riftes.

A Bacia de Curitiba tem sido tradicionalmente relacionada ao SRCSB (Almeida 1976, Melo et al. 1985, Riccomini 1989, Riccomini et al. 2004), embora Zalán \& Oliveira (2005) considerem que ela possa ser "uma mera depressão topográfica a meio caminho de dois blocos de falha rotacionados divergentemente". A questão da origem desta bacia e sua relação com o SRCSB deverá ser melhor compreendida após a conclusão de estudos em curso na região.

Geologia e geomorfologia local A Depressão do Piraí e a Bacia de Curitiba distam entre si aproximadamente $120 \mathrm{~km}$ em linha reta. Ambas situam-se no denominado Primeiro Planalto Paranaense, ou Planalto de Curitiba, onde dominam rochas ígneas e metamórficas do embasamento da Bacia do Paraná no Estado do Paraná.

DEPRESSÃO DO PIRAÍ A Depressão do Piraí aparece na forma de compartimento de relevo suavizado e rebaixado, contrastante com o relevo montanhoso próximo. O setor principal deste compartimento é alongado na direção NE-SW, com cerca de $15 \mathrm{~km}$ de extensão e $5 \mathrm{~km}$ de largura (Fig. 2).

O substrato geológico na região compreende rochas do Complexo Granítico Cunhaporanga (granitos, granitóides e quartzitos do final do Proterozóico), do Grupo Castro (riolitos, andesitos, tufos, ignimbritos, 
quartzo latitos, brechas, conglomerados polimíticos, arenitos arcoseanos, lamitos e siltitos do limite Proterozóico-Paleozóico), da Formação Furnas (arenitos e conglomerados siluro-devonianos) e diques associados ao Magmatismo Serra Geral (diabásios, dioritos, dioritos pórfiros cretáceos) (MINEROPAR 2001 e 2005a).

Muitas das rochas da região são ricas em feldspatos (granitos, granitóides, riolitos, ignimbritos), e seu intemperismo deu origem aos materiais que preenchem a depressão. O relevo no interior da depressão é de colinas suaves, com desníveis máximos de 40 metros entre os talvegues e topos. Mas nas vizinhanças ocorrem, a leste, a Serra das Pedras (quartzitos do Complexo Cunhaporanga) e a oeste relevo estrutural em rochas do Grupo Castro e a Escarpa Devoniana ${ }^{1}$, sustentada pela Formação Furnas. Os desníveis topográficos ultrapassam 300 metros de altitude.

Os sedimentos encontrados na Depressão do Piraí foram agrupados em fácies gravitacionais (lamitos), dominantes, e fácies fluviais (areias, argilas, cascalhos), presentes em menor quantidade (Lima inédito). As amostras analisadas (locais DC-52 e DC-54 na Fig. 2) provêm de lamitos argilosos da fácies gravitacional. A pequena espessura dos sedimentos (cerca de 30 metros) estaria indicando deslocamentos tectônicos menores ou ainda pronunciada erosão pós-sedimentar.

Análise das estruturas rúpteis das rochas do embasamento da Depressão do Piraí levou às seguintes conclusões (Lima inédito): movimentos tectônicos cenozóicos reativaram estruturas preexistentes; houve duas fases principais de deformação, a mais antiga distensiva e a mais jovem compressiva, reforçando a correlação com a evolução das bacias do SRCSB; não foi possível datar de forma absoluta os falhamentos e depósitos.

BACIA DE CURITIBA A Bacia de Curitiba é uma depressão alongada no sentido NE-SW com cerca de $3.000 \mathrm{~km}^{2}$ de superfície (Fig. 3), situada no alto Rio Iguaçu, na Região Metropolitana de Curitiba.

O substrato rochoso da região inclui litotipos muito diversificados, do Mesoproterozóico a Arqueano (Grupo Setuva, "Complexo Granítico-Gnáissico", "Complexo Gnáissico-Migmatítico" e "Complexo Metamórfico Indiferenciado", incluindo xistos, mármores, quartzitos, granitos, gnaisses, metagabros, migmatitos, granitos foliados como principais litotipos), do Neoproterozóico (Grupo Açungui, incluindo diversos tipos de metassedimentos terrígenos e carbonáticos), do $\mathrm{Ne}$ oproterozóico a Cambriano (suítes graníticas), formações Camarinha (rochas sedimentares terrígenas do Neoproterozóico a Cambriano) e Guaratubinha (seqüência vulcano-sedimentar do Ordoviciano-Cambriano) e diques de rochas básicas (diabásio, gabro, diorito pórfiro do Mesozóico) (MINEROPAR 2005b e 2005c).

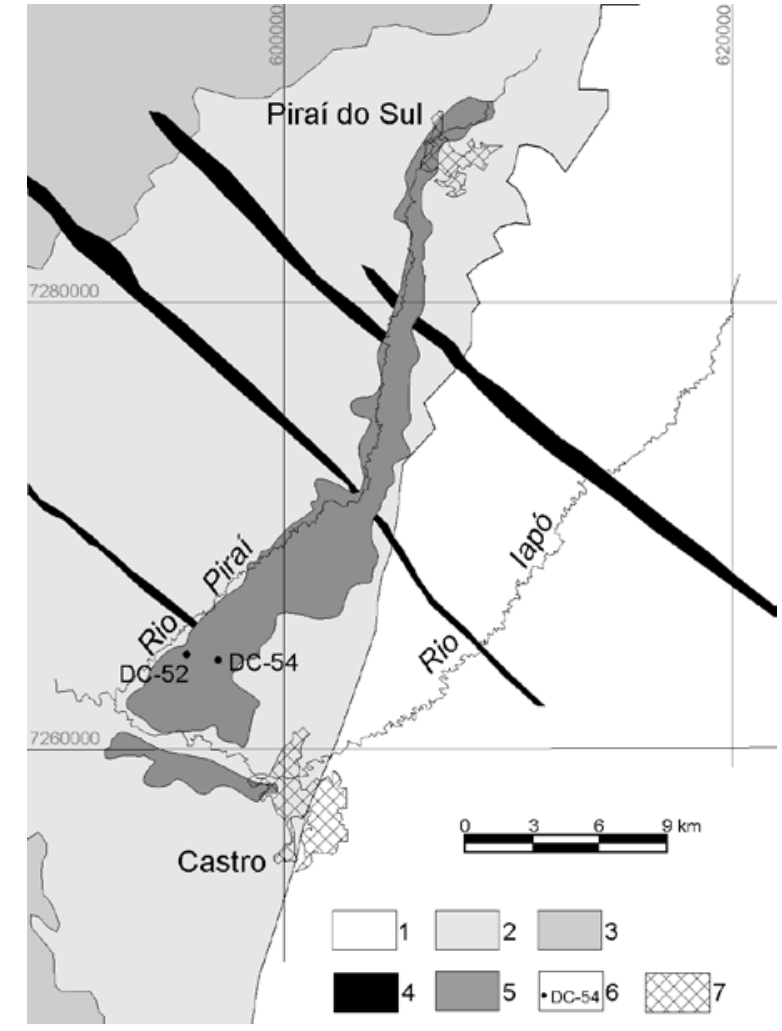

Figura 2 - Mapa geológico simplificado da região da Depressão do Piraí. 1) Complexo Granítico Cunhaporanga; 2) Grupo Castro; 3) Formação Furnas; 4) principais diques relacionados ao Magmatismo Serra Geral; 5) depósitos cenozóicos da Depressão do Piraí; 6) locais de coleta das amostras analisadas; 7) áreas urbanas (baseado em MINEROPAR 2005a e Lima inédito).

As características do substrato rochoso da Bacia de Curitiba influenciam marcadamente a natureza dos sedimentos cenozóicos, como é o caso da presença freqüente de calcretes sobretudo nas porções próximas dos metassedimentos carbonáticos do Grupo Açungui.

Os sedimentos da Bacia de Curitiba têm sido agrupados na Formação Guabirotuba (Bigarella \& Salamuni 1962), compreendendo argilas, arcóseos, depósitos rudáceos e lamas com carbonatos, com cor predominante cinza a cinza-esverdeada, interpretados como tendo sido formados em leques aluviais (Coimbra et al. 1996). Outros autores chegaram a propor unidades para englobar alteritos e/ou depósitos mais tipicamente fluviais (formações Tinguis e Boqueirão de Becker 1982, Formação Piraquara de Coimbra et al. 1996), mas sua existência ainda é questionada.

O relevo da região da Bacia de Curitiba é suavemente ondulado com altitudes variando de 750 a 980 metros, com a presença de colinas e vales, estes

1 Adota-se a denominação "Escarpa Devoniana” por ser consagrada pelo uso. Na verdade a feição de relevo é pós-ruptura continental e, portanto, de idade cretácea a mais recente, enquanto as rochas que sustentam a escarpa, arenitos da Formação Furnas, são aqui admitidas como siluro-devonianas. 


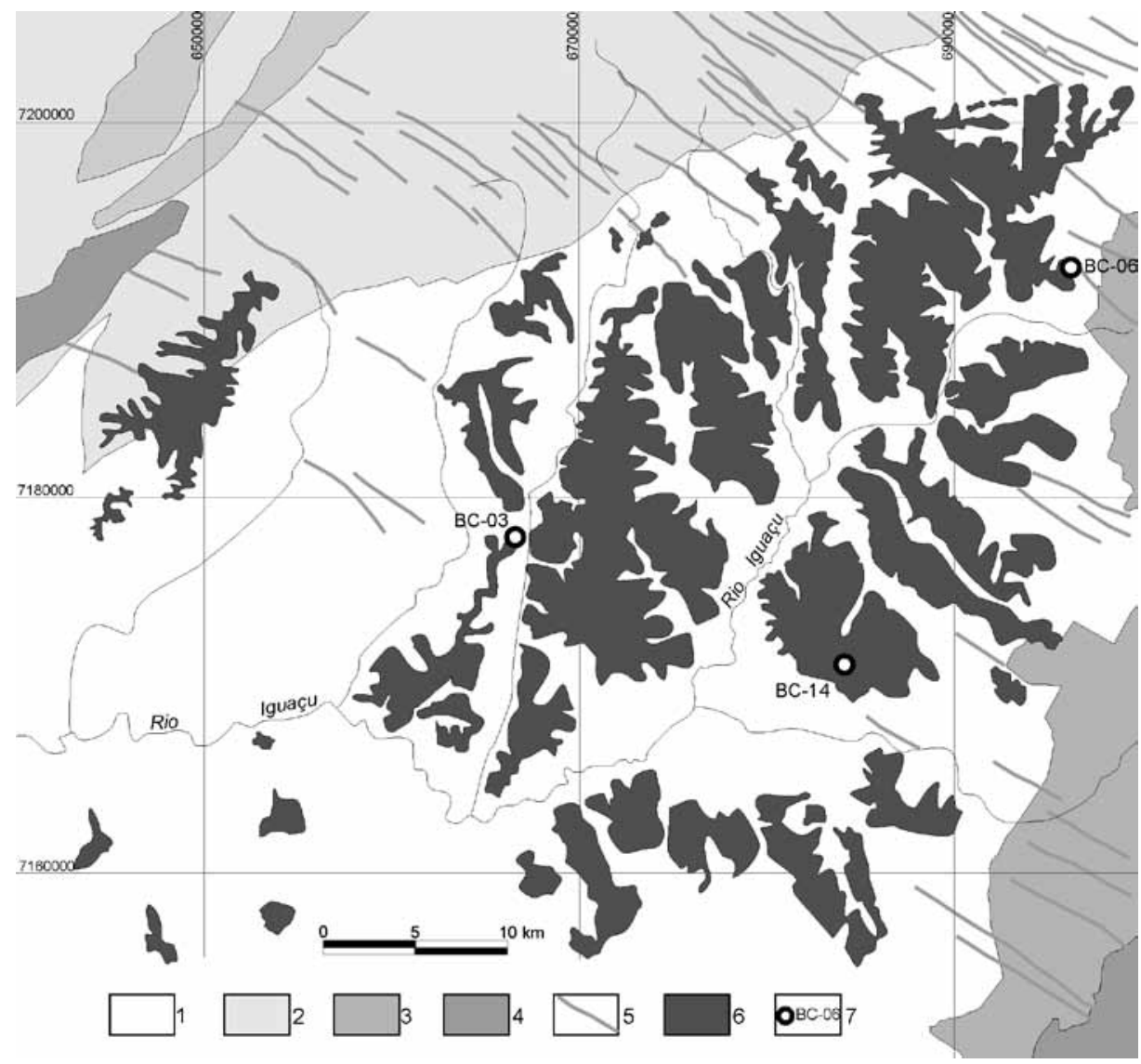

Figura 3 - Mapa geológico simplificado da região da Bacia de Curitiba. 1) rochas do Mesoproterozóico a Arqueano; 2) Grupo Açungui (Neoproterozóico); 3) granitóides, granitos e migmatitos (Neoproterozóico a Cambriano); 4) Formações Camarinha e Guaratubinha (Ordoviciano); 5) principais diques relacionados ao Magmatismo Serra Geral; 6) Formação Guabirotuba (Cenozóico); 7) locais de coleta das amostras analisadas (baseado em Salamuni 1998, MINEROPAR 2001 e 2005b).

contendo sedimentos aluviais recentes em amplas planícies que se estendem por mais de $800 \mathrm{~km}^{2}$. A bacia é ladeada por dois altos topográficos: o primeiro, a leste e sudeste, é representado pelos granitos da Serra do Mar, com cotas entre 1.100 e $1.200 \mathrm{~m}$; o segundo situado a oeste-noroeste, é formado pelos metassedimentos do Grupo Açungui, com altitudes médias de $950 \mathrm{~m}$ e picos de até $1.100 \mathrm{~m}$ (Salamuni et al. 2004).

A espessura máxima preservada de sedimentos na Bacia de Curitiba é de cerca de 80 a 100 metros. A deposição foi controlada pelas falhas normais de direção NE-SW presentes na borda noroeste, NNE-SSW na borda sudeste e N-S na borda leste (Salamuni 1998). É admitida a idade oligo-miocênica para a Formação Guabirotuba, sobretudo por correlação com as outras bacias do SRCSB.

MATERIAIS E MÉTODOS A metodologia utilizada para estudo dos materiais argilosos envolveu análises para caracterização mineralógica dos sedimentos e ensaios tecnológicos para identificação de suas possíveis aplicações.

As análises de caracterização mineralógica dos sedimentos incluíram microscopia eletrônica de varredura (MEV) com espectroscopia de energia dispersiva (EDS), difratometria de raios X (DRX), fluorescência de raios X (FRX), análise termodiferencial (ATD) e análise termogravimétrica (ATG). Estas análises seguiram procedimentos usuais. A distinção entre cristais de minerais neoformados (diagenéticos) e detríticos baseou-se na identificação visual do hábito (pouco ou não reconhecível nos detríticos) e na comparação da imagem e curva de EDS com atlas (Welton 1984).

Para MEV e EDS foram utilizados fragmentos milimétricos das amostras in natura, previamente se$\cos \left(24\right.$ horas a temperatura de cerca de $\left.40^{\circ} \mathrm{C}\right)$ e metalizados com ouro. As análises de MEV e EDS foram feitas num equipamento Shimadzu, modelo SSX-550, com EDS acoplado, no Departamento de Engenharia de Materiais (DEMA) da Universidade Estadual de Ponta Grossa (UEPG). As fotomicrografias obtidas foram comparadas com as presentes em Welton (1984) para apoio à caracterização dos minerais e distinção entre origem detrítica e diagenética. As análises EDS foram realizadas com feixe de elétrons de $1 \mu \mathrm{m}$ de raio e 3.000 contagens para o pico mais intenso. 
As análises de DRX para identificação dos minerais presentes foram realizadas num difratômetro Shimadzu XRD-6000 no DEMA/UEPG, nas seguintes condições: $2 \theta$ variando de 5 a $90^{\circ}$, velocidade de varredura de $2 \%$ min e radiação de $\mathrm{Cu}-\mathrm{K}_{\alpha}$. Foram utilizadas lâminas preparadas com alíquotas das amostras totais, sem separação prévia por decantação ou outros métodos, com o objetivo de que os materiais analisados correspondessem aos materiais constituintes dos corpos de prova utilizados nas caracterizações tecnológicas dos sedimentos.

A análise química foi realizada por FRX num equipamento modelo EDX 700 da Shimadzu no DEMA/ UEPG.

A ATD e ATG foram realizadas no LAMIR - Laboratório de Análise de Minerais e Rochas - da Universidade Federal do Paraná (UFPR), em um analisador térmico diferencial e termogravimétrico simultâneo usando amostras de argila seca em temperatura de $110{ }^{\circ} \mathrm{C}$ tendo alumina como material inerte, com taxa de aquecimento de $10{ }^{\circ} \mathrm{C} / \mathrm{min}$, até uma temperatura de $1500^{\circ} \mathrm{C}$.

Os ensaios tecnológicos seguiram em linhas gerais as prescrições para caracterização preliminar de argilas desconhecidas visando prever usos industriais, em especial em cerâmica (Santos 1989). A preparação prévia das amostras envolveu secagem em estufa a temperatura em torno de $110^{\circ} \mathrm{C}$ por cerca de 5 dias, destorroamento e moagem manuais. Todos os ensaios foram realizados no Laboratórios do DEMA/UEPG.

Para a realização desses ensaios, corpos-deprova com dimensões de $6 \mathrm{~cm} \times 2 \mathrm{~cm} \times 0,5 \mathrm{~cm}$ foram conformados por prensagem uniaxial de $20 \mathrm{MPa}$. Seguiu-se procedimento padrão (Santos 1989): após secagem em estufa a $110^{\circ} \mathrm{C}$, os corpos-de-prova foram queimados a 950,1100 e $1200^{\circ} \mathrm{C}$, com taxa de aquecimento de $10^{\circ} \mathrm{C} / \mathrm{min}$ e patamar de queima de 1 hora.

Os corpos-de-prova após queima foram caracterizados por medidas de adsorção de água (AA), porosidade aparente (PA), massa específica aparente (MEA), retração linear (RL) e perda ao fogo $(\mathrm{PF})$, todas feitas pelo método de imersão em água (Santos 1989). Módulo de ruptura à flexão foi determinado pelo método de flexão em três pontos num flexímetro Nannetti - FM96.

Procedência das amostras estudadas A tabela 1 apresenta a relação das seis amostras analisadas, três da Depressão do Piraí e três da Bacia de Curitiba. A localização dos afloramentos onde foram coletadas está apresentada nas figuras 2 e 3 . Os materiais argilosos amostrados correspondem a lamas argilosas (fácies gravitacionais) ou argilas de suspensão (fácies fluviais e/ou lacustres). Apesar do caráter argiloso das amostras, às vezes permanece dúvida quanto à origem gravitacional ou de suspensão, pois existe a possibilidade de transição e/ou coexistência entre os processos gravitacionais e de suspensão na proximidade de corpos aquosos no ambiente deposicional.

\section{RESULTADOS E DISCUSSÕES}

Microscopia eletrônica de varredura (MEV) e espectrometria de energia dispersiva (EDS) As figuras 4, $5,6,7$ e 8 são fotomicrografias obtidas por emissão de elétrons secundários com MEV das amostras da Depressão do Piraí e da Bacia de Curitiba. A interpretação da composição mineralógica apoiou-se na morfologia observada comparada com os dados de Welton (1984) e também em análises de EDS realizadas nos cristais ou massas cristalinas estudadas. A distinção entre cristais diagenéticos (neoformados) e detríticos baseou-se na preservação ou não do hábito dos minerais, o qual tende a euedral no primeiro caso e anedral no segundo.

Algumas interpretações que emergem dos estudos de MEV e EDS são:

a) as argilas na Depressão do Piraí são essencialmente cauliníticas, predominando argilas detríticas (Figs. 4 e 5);

b) a presença de grãos de quartzo subédricos (Fig. $4 \mathrm{C}$ e D) nos sedimentos da Depressão do Piraí possivelmente indica proximidade da área-fonte (rochas do Grupo Castro);

c) na Bacia de Curitiba aparecem caulinita detrítica e diagenética (Fig. 8C e D), bem como ilita fibrosa (Fig. 6C) e argila do grupo da esmectita (Figs. $6 \mathrm{~A}, 7 \mathrm{~A}$ e B, $8 \mathrm{~A}$ e B) diagenéticas; cristais de esmectita passando a ilita fibrosa (Figs. 6B e C) indicam ilitização diagenética;

d) cristais de dolomita autigênica nos sedimentos da Bacia de Curitiba (Fig. 6D) indicam a influência das áreas-fontes carbonáticas, principalmente rochas do Grupo Açungui.

Fluorescência de raios X (FRX) Os resultados das análises de FRX realizadas (Tab. 2) indicam teores mais expressivos de $\mathrm{SiO}_{2}$ e $\mathrm{Al}_{2} \mathrm{O}_{3}$, indicativos de predomínio de quartzo e dos argilominerais do grupo da

Tabela 1 - Localização e descrição de campo das amostras analisadas procedentes da Depressão do Piraí (DC) e da Bacia de Curitiba (BC).

\begin{tabular}{l|l|l|l|l}
\hline Amostra & Local & Lat. UTM & Long. UTM & Material \\
\hline DC-52A & Depressão do Piraí & 7.263 .545 & 596.400 & Lamito argiloso gravitacional mosqueado \\
\hline DC-54A & Depressão do Piraí & 7.264 .019 & 597.009 & Argila de suspensão mosqueada \\
\hline DC-54B & Depressão do Piraí & 7.264 .019 & 597.009 & Lamito argilo-arenoso gravitacional mosqueado \\
\hline BC-03D & Bacia de Curitiba & 7.177 .785 & 666.700 & Argila de suspensão esverdeada \\
\hline BC-06D & Bacia de Curitiba & 7.193 .062 & 696.432 & Argila gravitacional esverdeada \\
\hline BC-14 & Bacia de Curitiba & 7.171 .089 & 684.142 & Argila de suspensão cinza clara \\
\hline
\end{tabular}



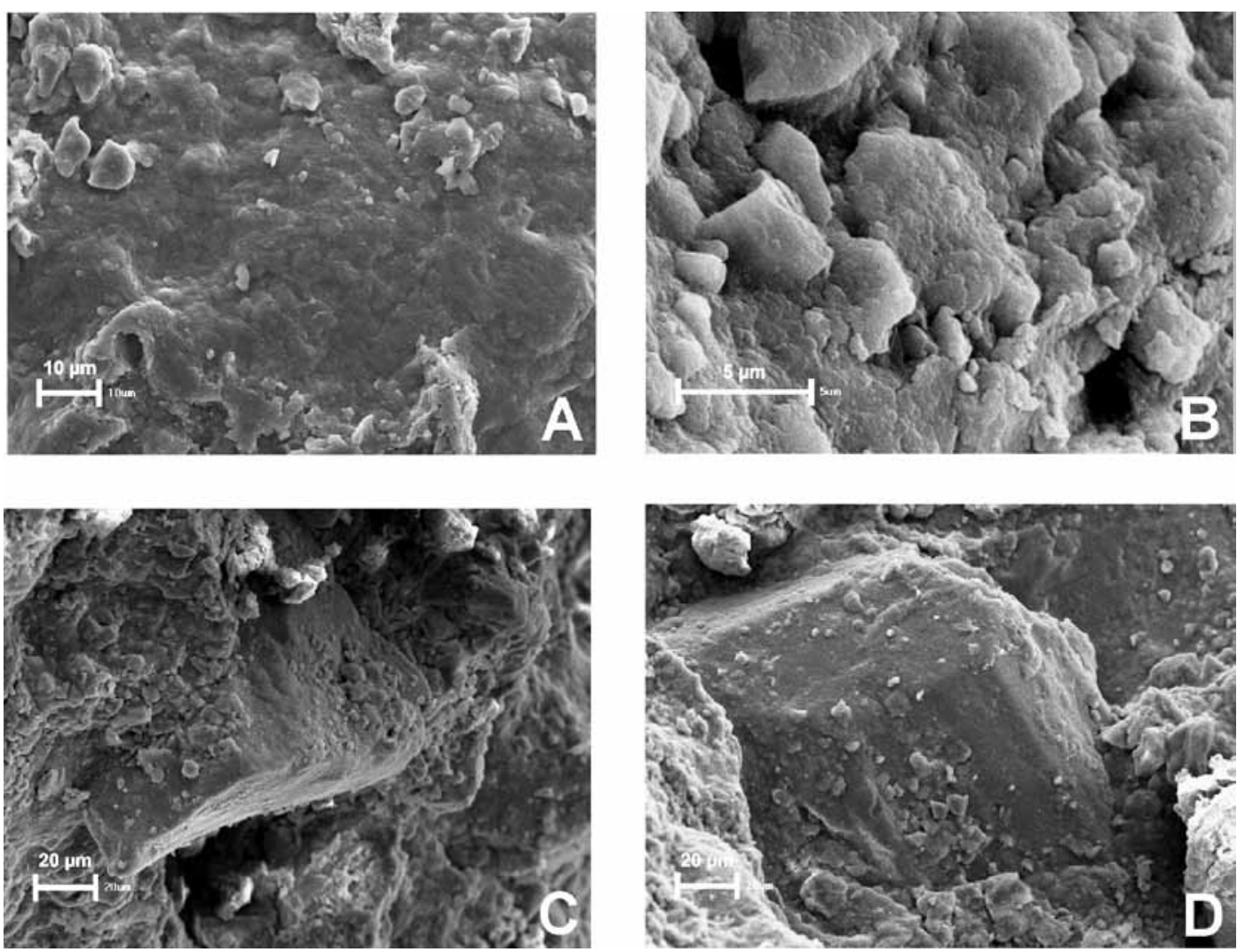

Figura 4 - minerais constituintes da amostra DC-54A (Depressão do Pirai): A e B) caulinita maciça de aspecto detrítico; $C$ e D) grãos de quartzo subédricos recobertos por caulinita de aspecto detrítico (imagens MEV/elétrons secundários).
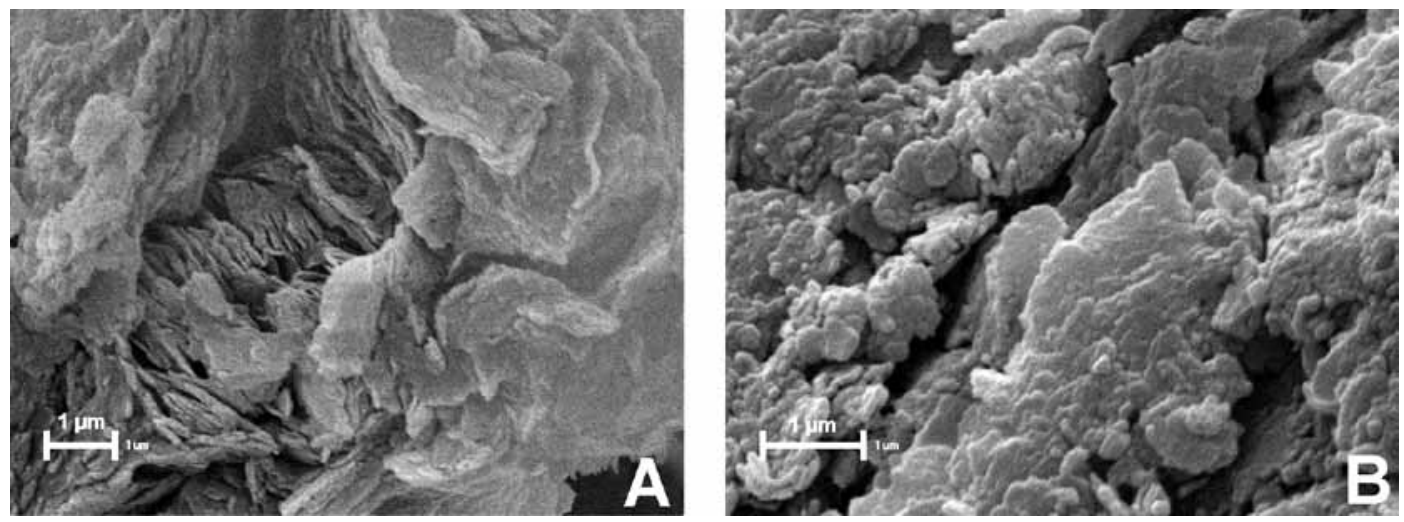

Figura 5 - minerais constituintes da amostra DC-54B (Depressão do Piraí): A) caulinita de aspecto diagenético, pouco desarticulada; B) caulinita maciça de aspecto detrítico (imagens MEV/elétrons secundários).

caulinita. $\mathrm{O}$ teor, não muito expressivo, de $\mathrm{K}_{2} \mathrm{O}$ pode indicar argilominerais do grupo da ilita e feldspatos. Também foi constatada na amostra $\mathrm{BC}-03 \mathrm{D}$ a presença de $\mathrm{CaO}$ e $\mathrm{MgO}$, corroborando a identificação de dolomita realizada ao MEV/EDS, de calcita e dolomita identificadas por DRX (Fig. 9) e de mineral do grupo da esmectita, realizada ao MEV/EDS. Já o $\mathrm{Fe}_{2} \mathrm{O}_{3}$ pode indicar hematita, goethita ou pirita. As duas primeiras são as responsáveis pela coloração avermelhada a marrom amarelada característica dos sedimentos oxidados e de telhas e blocos cerâmicos.

Difratometria de raios X (DRX) Nos difratogramas de amostras totais analisadas (Fig. 9) foi possível confirmar alguns dos minerais identificados nas análises MEV e EDS. As amostras da Depressão do Piraí apresentam picos indicativos de caulinita e quartzo, sendo que a amostra DC-54B também possui picos indicativos de 

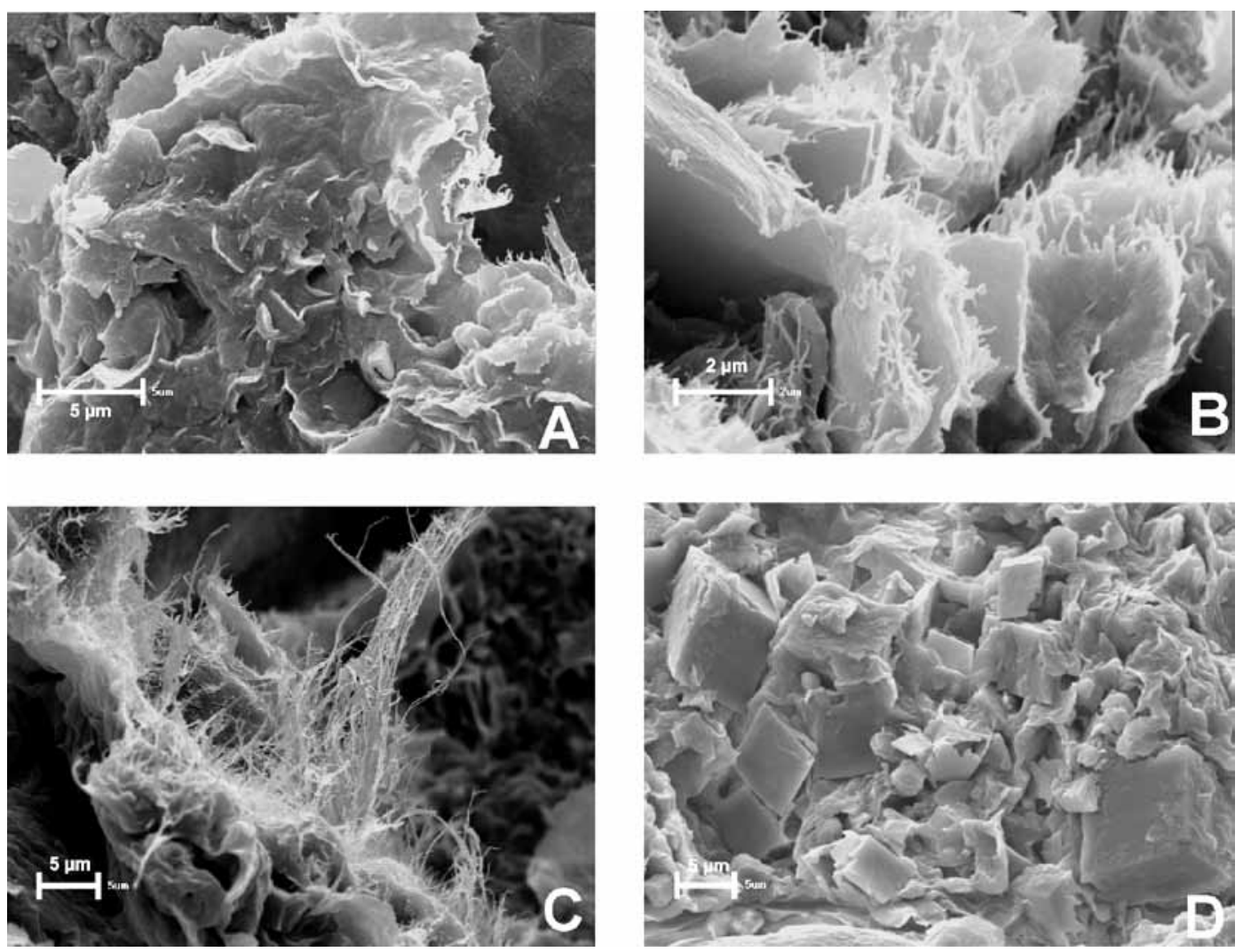

Figura 6 - minerais constituintes da amostra BC-03D (Bacia de Curitiba): A) esmectita de aspecto diagenético; $B$ ) detalhe de esmectita de aspecto diagenético com bordas ilitizadas; C) ilita fibrosa de aspecto diagenético; D) cristais de dolomita (imagens MEV/ elétrons secundários).
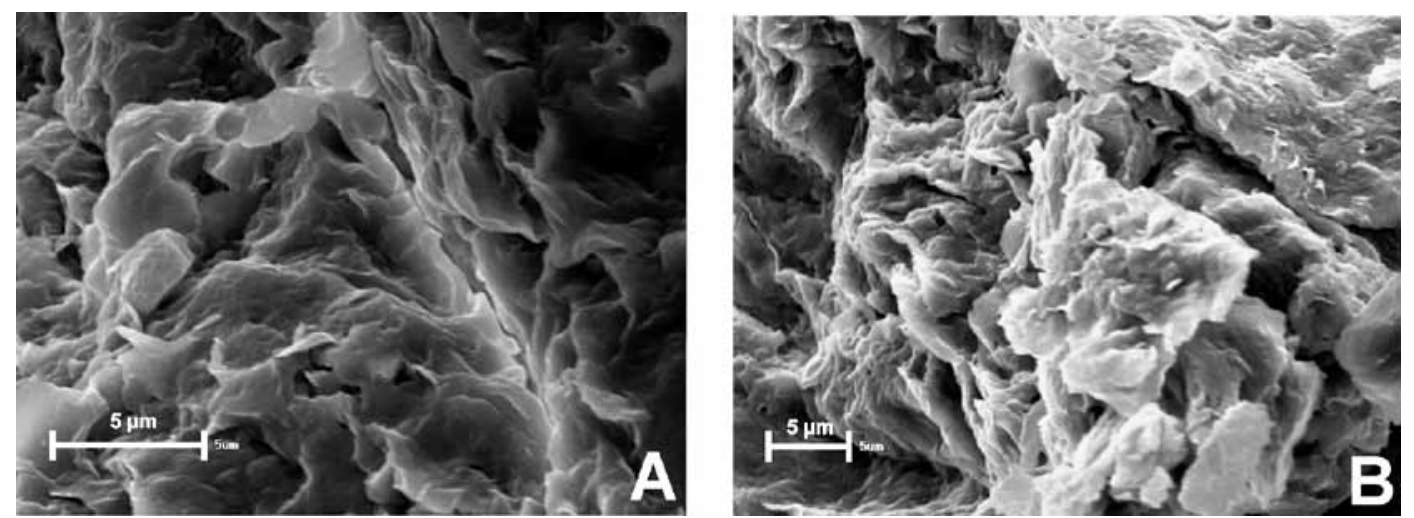

Figura 7 - minerais constituintes da amostra BC-06D (Bacia de Curitiba): A e B) esmectita de aspecto diagenético (imagens MEV/elétrons secundários).

feldspato. Nas amostras da Bacia de Curitiba, além da presença de quartzo e caulinita foram observados também picos de calcita e dolomita e, na amostra BC-06D, também foi detectado feldspato. Como pôde ser observado na análise de fluorescência de raios $\mathrm{X}$, as amostras DC-54B e BC-06D apresentam $\mathrm{K}_{2} \mathrm{O}$, confirmando o feldspato. A amostra BC-03D apresenta $\mathrm{CaO}$ e $\mathrm{MgO}$, confirmando a presença de calcita e dolomita. Apesar da constatação de $\mathrm{Fe}_{2} \mathrm{O}_{3}$ nas análises por $\mathrm{FRX}$, nos ensaios de DRX não foram encontrados picos relativos a minerais que apresentem $\mathrm{Fe}_{2} \mathrm{O}_{3}$ em sua composição.

Análises termodiferenciais (ATD) e termogravimétricas (TG) Para as amostras da Depressão do Piraí (DC-52A, DC-54A e DC-54B na Fig. 10), os resultados de ATD/TG foram bastante similares. Na ATD, as amostras exibiram picos endotérmicos próximos à temperatura de $100{ }^{\circ} \mathrm{C}$, associados à liberação da 

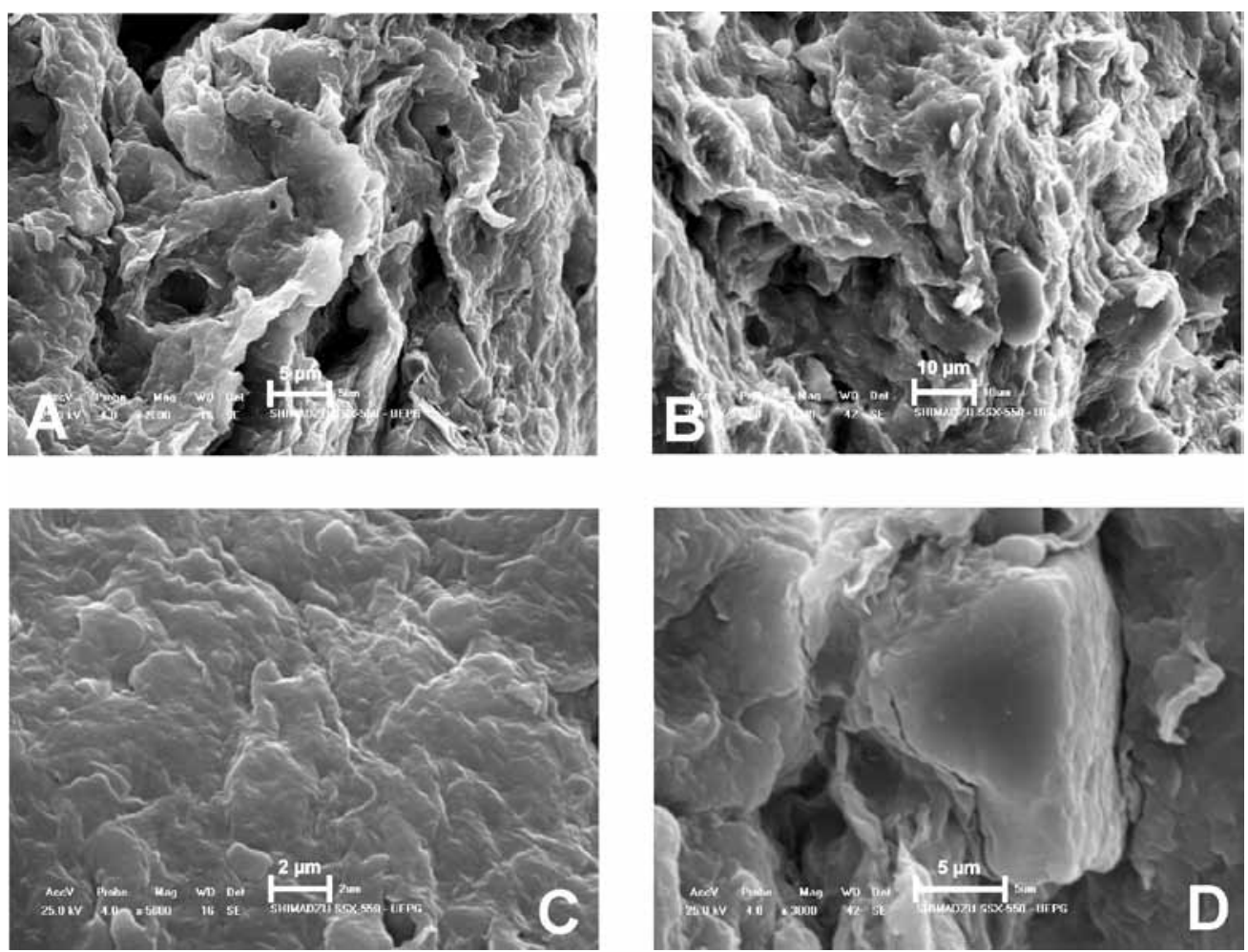

Figura 8 - minerais constituintes da amostra BC-14 (Bacia de Curitiba): A e B) esmectita de aspecto diagenético; C) caulinita maciça de aspecto detrítico; D) caulinita de aspecto diagenético (imagens MEV/elétrons secundários).

Tabela 2 - Resultados (porcentagem em peso) das análises por fluorescência de raios $X$ das amostras analisadas procedentes da Depressão do Pirai (DC) e da Bacia de Curitiba (BC).

\begin{tabular}{l|c|c|c|c|c|c|c|c}
\hline Amostras & $\mathrm{SiO}_{2}$ & $\mathrm{Al}_{2} \mathrm{O}_{3}$ & $\mathrm{Fe}_{2} \mathrm{O}_{3}$ & $\mathrm{~K}_{2} 0$ & $\mathrm{TiO}_{2}$ & $\mathrm{SO}_{3}$ & $\mathrm{CaO}$ & $\mathrm{MgO}$ \\
\hline DC-52A & 59,90 & 25,37 & 10,12 & 1,43 & 3,15 & -- & -- & -- \\
\hline DC-54A & 69,90 & 22,87 & 2,61 & 0,84 & 2,26 & 1,46 & -- & -- \\
\hline DC-54B & 60,61 & 23,00 & 7,91 & 5,70 & 1,45 & 0,09 & 1,15 & -- \\
\hline BC-03D & 45,51 & 10,35 & 4,84 & 1,83 & 1,46 & -- & 28,94 & 6,85 \\
\hline BC-06D & 60,25 & 21,82 & 7,62 & 5,59 & 1,44 & 2,06 & 1,10 & -- \\
\hline BC-14 & 60,68 & 24,59 & 7,86 & 2,65 & 1,30 & 2,18 & 0,62 & -- \\
\hline
\end{tabular}
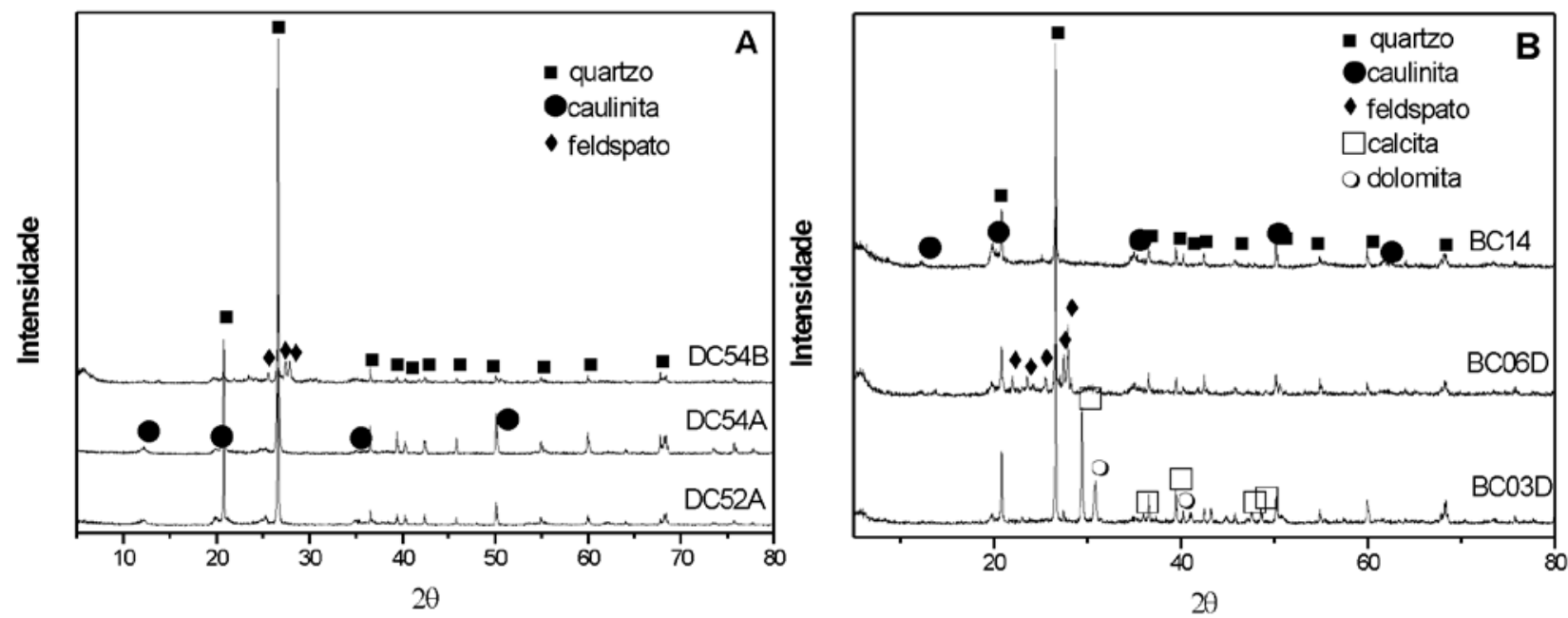

Figura 9 - Difratogramas das amostras de sedimentos argilosos analisadas. A) amostras da Depressão do Piraí; B) amostras da Bacia de Curitiba. 
água livre, e picos também endotérmicos próximos às temperaturas de $500{ }^{\circ} \mathrm{C}$ e $600{ }^{\circ} \mathrm{C}$, associados à liberação da água estrutural proveniente dos minerais argilosos e à transformação alotrópica do quartzo $\alpha$ para o quartzo $\beta$. A $960{ }^{\circ} \mathrm{C}$ ocorre um pico exotérmico característico das argilas cauliníticas, o qual está associado à nucleação da mulita. As três amostras apresentaram pico endotérmico de grande intensidade com valor máximo em torno de $1350^{\circ} \mathrm{C}$, correspondente à formação da fase vítrea do material. As amostras DC54A e DC-54B apresentaram um aumento da intensidade deste pico próximo a $1200^{\circ} \mathrm{C}$, mais evidente na DC-54B. Esta redução na temperatura de formação de fase vítrea pode estar associada à presença de feldspa- to, corroborando os resultados de DRX.

Para as amostras da Bacia de Curitiba (BC-03D, BC-06D e BC-14), assim como nas amostras da Depressão do Piraí, são verificados os picos de ATD relativos à eliminação de água livre próximo a $100{ }^{\circ} \mathrm{C}$ e picos endotérmicos associados à perda de hidroxilas dos materiais argilosos e à transformação do quartzo $\alpha \mathrm{em}$ quartzo $\beta$ entre 500 e $600{ }^{\circ} \mathrm{C}$. Na amostra BC-03D, na temperatura próxima a $800{ }^{\circ} \mathrm{C}$, aparece um pico endotérmico que está associado a decomposição da calcita e da dolomita, com liberação de $\mathrm{CO}_{2}$. Esse resultado está de acordo com a FRX e a DRX, que mostraram a presença de $\mathrm{CaO}$ e $\mathrm{MgO}$ nessa amostra. Os picos endotérmicos de formação de fase vítrea aparecem com
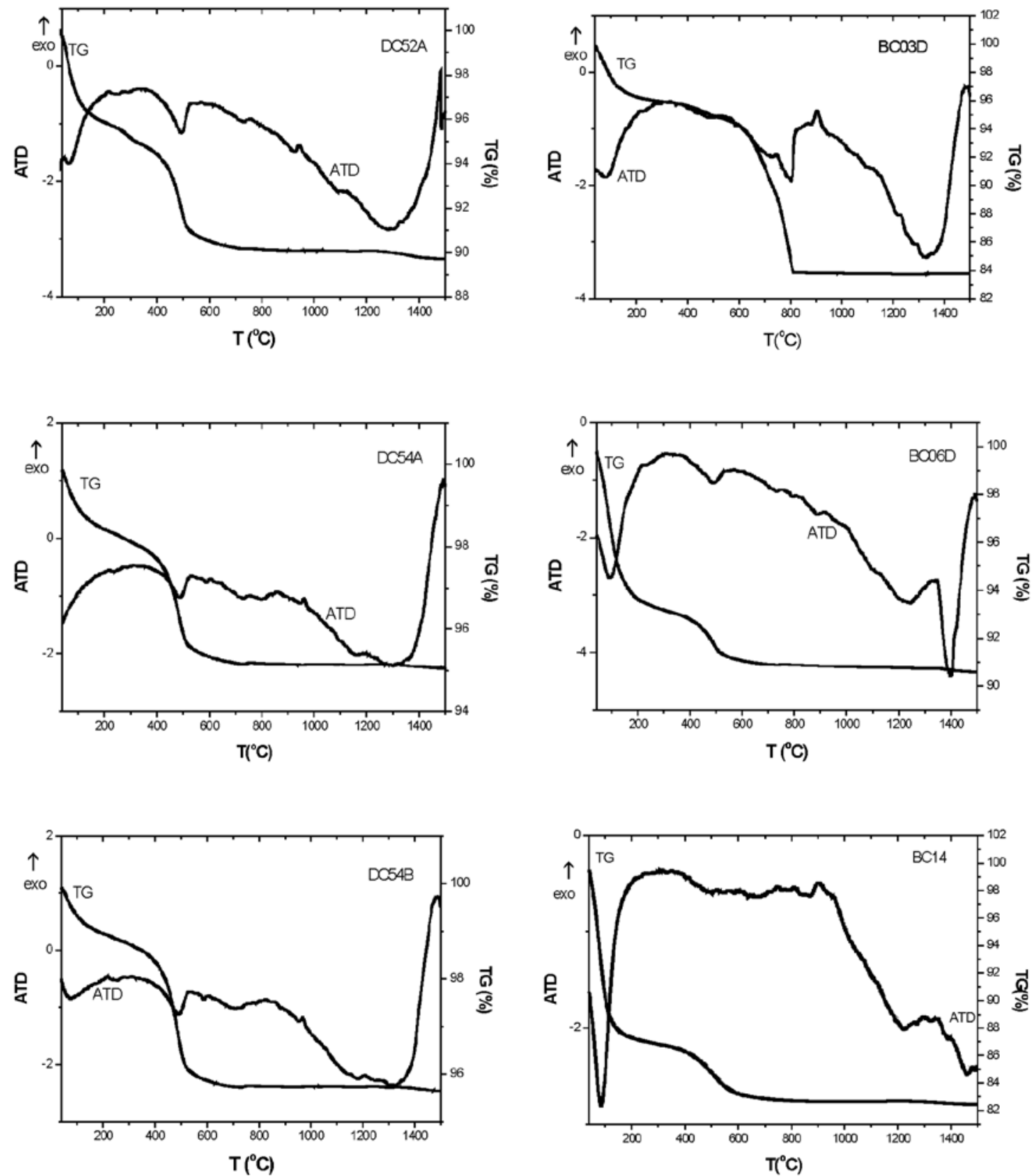

Figura 10 - Análise térmica diferencial (ATD, diferença de temperatura em $\left.{ }^{\circ} \mathrm{C}\right)$ e análise termogravimétrica (TG, porcentagem em peso) das amostras da Depressão do Piraí (DC) e da Bacia de Curitiba (BC). 
máxima intensidade próximo a $1450{ }^{\circ} \mathrm{C}$ para a amostra BC-14, próximo a $1400{ }^{\circ} \mathrm{C}$ para a amostra BC-03D e próximo a $1350{ }^{\circ} \mathrm{C}$ para a amostra $\mathrm{BC}-06 \mathrm{D}$, entretanto o início da formação de fase vítrea está abaixo destas temperaturas. Um segundo pico endotérmico próximo a $1200{ }^{\circ} \mathrm{C}$ foi encontrado nas amostras BC-06D e BC-14.

Nos resultados de ATG a amostra DC-52A apresentou perda de massa em torno de $10 \%$, enquanto que para as amostras DC-54A e DC-54B a queda de massa ficou em torno de 5\%. A perda de massa ocorre de forma mais acentuada em duas faixas de temperatura. A primeira está próxima de $100{ }^{\circ} \mathrm{C}$ e está relacionada à perda de água livre. Já a segunda ocorre aproximadamente em $500{ }^{\circ} \mathrm{C}$ e está associada à perda de água estrutural. Entre 200 e $400{ }^{\circ} \mathrm{C}$ ocorre a perda de matéria-orgânica, que pode ser verificada pela contínua perda de massa. Este comportamento é característico de argilas, e também foi observado para as amostras BC06D e BC-14. A amostra BC-03D apresentou perdas de massa de forma acentuada próximo a $100{ }^{\circ} \mathrm{C}$, característica de perda de água livre, e próximo a $800^{\circ} \mathrm{C}$, que está associada à decomposição da calcita e da dolomita, com liberação de $\mathrm{CO}_{2}$.

Caracterização física das amostras A tabela 3 apresenta a perda ao fogo e a retração linear dos materiais argilosos da Depressão do Piraí e da Bacia de Curitiba. Pode-se observar que a amostra BC-03D apresenta a maior perda ao fogo, devido à liberação de $\mathrm{CO}_{2}$ a temperaturas superiores a $800^{\circ} \mathrm{C}$ durante a decomposição da calcita e da dolomita (Figs. 6D e 9). Outro fator bastante representativo na perda ao fogo das argilas é a decomposição dos minerais argilosos, carbonatos, sulfatos, remoção de água estrutural, água de hidróxidos e combustão de matéria orgânica. Estes resultados de perda ao fogo corroboram os valores encontrados na TG.

Quanto aos resultados de retração, cinco amostras não apresentam retração com o aumento de temperatura, DC-54B é a única que apresenta uma pequena retração. Estes resultados associados aos valores de porosidade aparente, absorção de água e densidade aparente, apresentados nas Figs. 11, 12 e 13, respectivamente, mostram que nos ensaios realizados não se atingiu a temperatura de sinterização adequada para a eliminação da porosidade das amostras. Vale ressaltar que a absorção de água, a porosidade aparente e a densidade aparente podem ser utilizadas para avaliar o processo de sinterização de cerâmicas e também para classificar o uso dessas cerâmicas.

As amostras DC-52A e BC-14 apresentaram um aumento de retração linear com o aumento de temperatura. Isso pode ser atribuído à formação da fase líquida que preenche a porosidade e promove a aproximação das partículas. A temperatura de formação da fase líquida é estimada com base no aumento da retração linear. No caso da amostra DC-52A observou-se que ocorreu grande retração entre 1100 e $1200^{\circ} \mathrm{C}$. Já para a amostra $\mathrm{BC}-14$ a grande retração ocorreu entre 950 e $1100^{\circ} \mathrm{C}$. A absorção de água e a porosidade aparente dessas amostras (Fig. 11 e 12) também diminuem com o aumento da temperatura, enquanto a densidade aparente (Fig. 13) aumenta com o aumento de temperatura. Esse comportamento é conseqüência da redução da porosidade aberta associada ao processo de sinterização das amostras.

A amostra BC-06D apresenta a maior retração a $1100{ }^{\circ} \mathrm{C}(12,8 \%)$ e a $1200{ }^{\circ} \mathrm{C}$ a retração linear diminui $(4,89 \%)$. A porosidade aparente e a absorção de água dessa amostra diminuem com o aumento da temperatura, mas a densidade aparente acompanha o comportamento da retração linar, ou seja, é maior a $1100^{\circ} \mathrm{C}$ e depois diminui a $1200^{\circ} \mathrm{C}$. Esse comportamento é típico de superqueima, no qual a porosidade fechada começa a coalescer, provocando um aumento no tamanho da amostra e uma diminuição de densidade aparente (Fig. 13).

$\mathrm{Na}$ temperatura de $1200^{\circ} \mathrm{C}$, a amostra BC-03D teve grande retração e arredondamento dos cantos. Isto provavelmente ocorreu devido à grande quantidade de fase líquida formada entre 1100 e $1200{ }^{\circ} \mathrm{C}$. Nas figuras 11 e 12 é possível observar para esta amostra os mais baixos valores de absorção de água e porosidade

Tabela 3 - Resultados dos ensaios de variação linear ou perda ao fogo (PF) a $1100^{\circ} \mathrm{C}$ e de perda de massa $\left(R L_{Q}\right)$ a 950, 1100 e $1200^{\circ} \mathrm{C}$ das amostras analisadas procedentes da Depressão do Pirai (DC) e da Bacia de Curitiba (BC).

\begin{tabular}{l|c|c|c|c}
\hline Amostra & $\begin{array}{c}\mathrm{PF}(\%) \\
1100{ }^{\circ} \mathrm{C}\end{array}$ & $\begin{array}{c}\mathrm{RL}_{\mathrm{Q}} 950 \\
{ }^{\circ} \mathrm{C}\end{array}$ & $\begin{array}{c}\mathrm{RL}_{\mathrm{Q}} 1100 \\
{ }^{\circ} \mathrm{C}\end{array}$ & $\begin{array}{c}\mathrm{RL}_{\mathrm{Q}} 1200 \\
{ }^{\circ} \mathrm{C}\end{array}$ \\
\hline DC-52A & 7,39 & 1,56 & 3,91 & 5,45 \\
\hline DC-54A & 4,6 & 0,44 & 0,46 & 0,83 \\
\hline DC-54B & 5,63 & $-0,27$ & $-0,2$ & $-0,17$ \\
\hline BC-03D & 16,53 & 2,69 & 2,49 & $\begin{array}{c}\text { perdeu a } \\
\text { forma }\end{array}$ \\
\hline BC-06D & 1,72 & 1,36 & 12,8 & 4,89 \\
\hline BC-14 & 7,36 & 3,28 & 7,05 & 9,02 \\
\hline
\end{tabular}

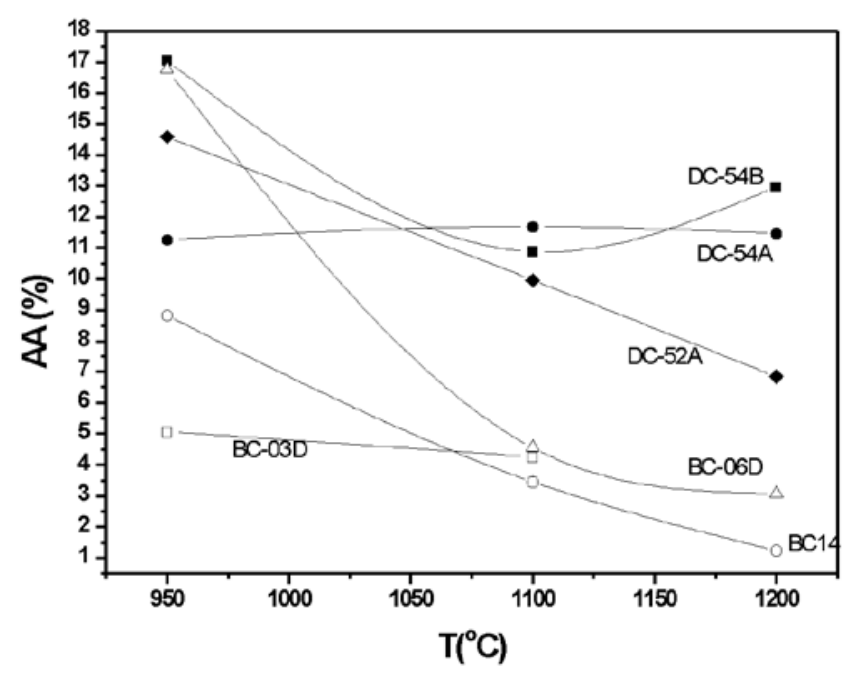

Figura 11 - Absorção de Água(AA) das amostras da Depressão do Piraí (DC) e da Bacia de Curitiba (BC). 


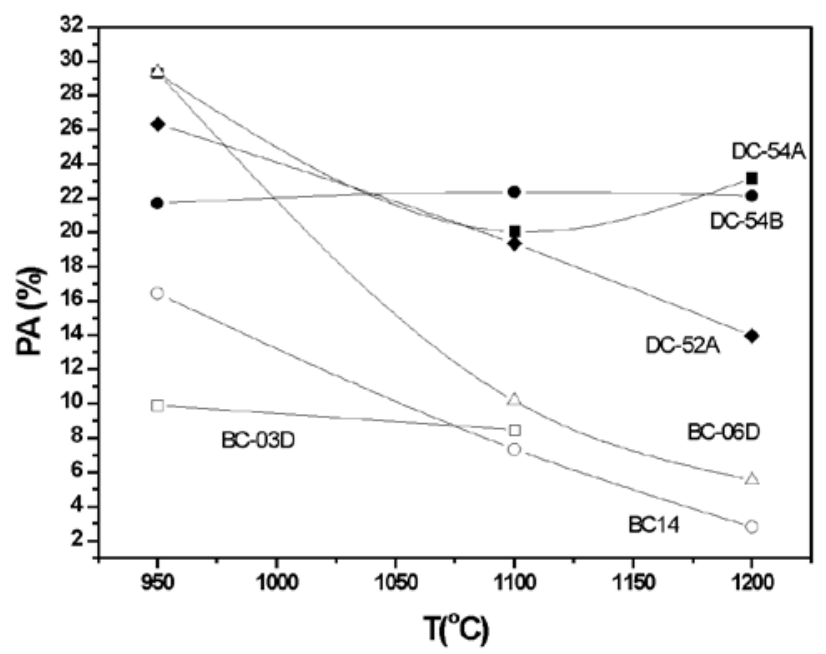

Figura 12 - Porosidade Aparente (PA) das amostras da Depressão do Piraí (DC) e da Bacia de Curitiba (BC).

aparente a $950{ }^{\circ} \mathrm{C}$. Entretanto houve pequena alteração destes valores na temperatura de $1100^{\circ} \mathrm{C}$.

A resistência mecânica das amostras após sinterização nas diferentes temperaturas é apresentada na tabela 4 e na figura 14. A resistência mecânica é fortemente dependente da microestrutura das cerâmicas, especialmente da presença de defeitos, tais como poros e trincas. Assim, ela está relacionada com a porosidade das amostras, ou seja, quanto maior a porosidade, menor a resistência mecânica. Juntamente com a absorção de água e porosidade aparente, a resistência mecânica é utilizada para classificação dos materiais cerâmicos.

As amostras DC-52A e BC-14 apresentaram um aumento da resistência com o aumento da temperatura, o que está de acordo com os resultados de porosidade aparente e absorção de água, que diminuem com o aumento da temperatura, e da densidade aparente, que aumenta com a temperatura. Na amostra BC-06D, a resistência mecânica diminui a $1200{ }^{\circ} \mathrm{C}$, confirmando a ocorrência de super-queima nessa amostra. As amostras DC-54A e DC-54B mostram os menores valores de módulo de ruptura, confirmando os resultados dos altos valores de absorção de água, porosidade aparente e densidade aparente.

A amostra BC-03D apresenta uma pequena diminuição da resistência entre 950 e $1100^{\circ} \mathrm{C}$, mostrando valores muito baixos de módulo de ruptura. Os dados da medida de módulo de ruptura a $1200{ }^{\circ} \mathrm{C}$ não puderam ser calculados devido à perda da forma desta amostra.

Cores de queima dos corpos de prova após sinterização A tabela 5 mostra os resultados das cores de queima dos corpos de prova das amostras estudadas, após sinterização a 950, 1100 e $1200{ }^{\circ} \mathrm{C}$. As cores de queima das amostras DC-52A e BC-06D são mais escuras, variando do bege avermelhado ao marrom escuro. As amostras com cores de queima mais claras foram DC54A, DC-54B e BC-03D (esta antes da fusão a $1200^{\circ} \mathrm{C}$ ).

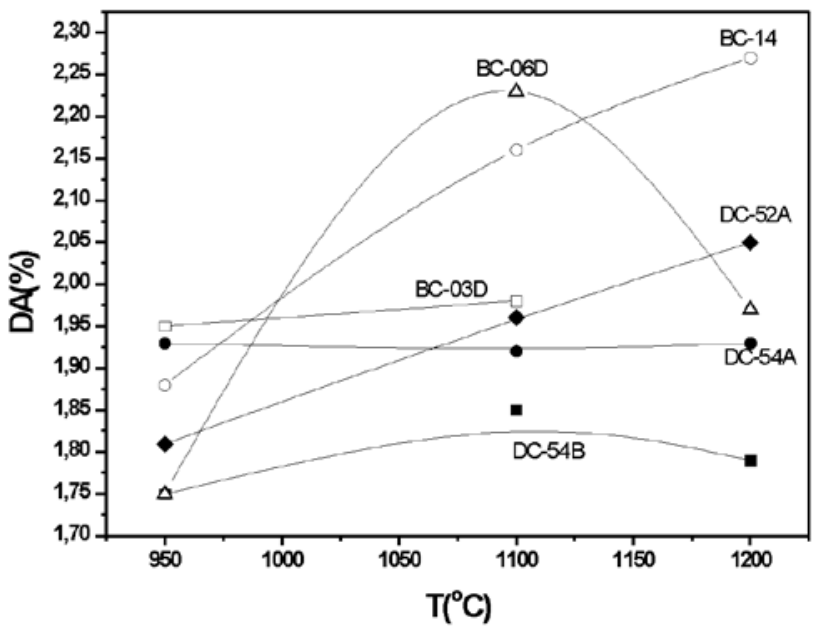

Figura 13 - Densidade Aparente (DA) das amostras da Depressão do Piraí (DC) e da Bacia de Curitiba (BC).

Tabela 4 - Módulo de ruptura à flexão dos corpos de prova das amostras de sedimentos argilosos da Depressão do Piraí e da Bacia de Curitiba.

\begin{tabular}{l|c|c|c}
\hline \multirow{2}{*}{ Amostras } & \multicolumn{3}{|c}{ Módulo de ruptura à flexão (MPa) } \\
\cline { 2 - 4 } & $950^{\circ} \mathrm{C}$ & $1100{ }^{\circ} \mathrm{C}$ & $1200{ }^{\circ} \mathrm{C}$ \\
\hline DC-52A & 4,5 & 6,0 & 10,6 \\
\hline DC-54A & 1,9 & 1,5 & 3,2 \\
\hline DC-54B & 1,0 & 0,8 & 0,8 \\
\hline BC-03D & 4,5 & 3,6 & $---*$ \\
\hline BC-06D & 1,2 & 23,8 & 21,3 \\
\hline BC-14 & 5,0 & 11,4 & 21,8 \\
\hline
\end{tabular}

* as amostras apresentaram arredondamento dos cantos, provavelmente devido ao excesso de fase líquida formada nessa temperatura

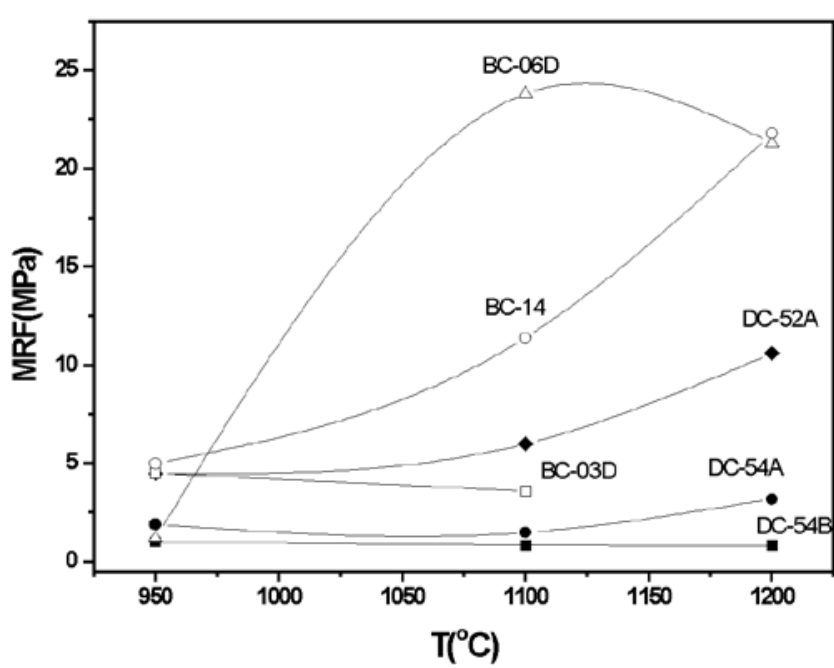

Figura 14 - Módulo de ruptura medido por flexão em três pontos das amostras da Depressão do Piraí (DC) e da Bacia de Curitiba (BC). 
Tabela 5 - Cores de queima dos corpos de prova das amostras de sedimentos argilosos da Depressão do Pirai e da Bacia de Curitiba após sinterização.

\begin{tabular}{c|c|c|c}
\hline \multirow{2}{*}{ Amostras } & \multicolumn{3}{|c}{ Cor de Queima } \\
\cline { 2 - 4 } DC-52A & $\begin{array}{c}\text { Bege } \\
\text { avermelhado }\end{array}$ & $\begin{array}{c}\text { Marrom claro } \\
\text { avermelhado }\end{array}$ & $\begin{array}{c}\text { Marrom claro } \\
\text { avermelhado }\end{array}$ \\
\hline DC-54A & Bege & Bege & $\begin{array}{c}\text { Bege claro } \\
\text { amarelado }\end{array}$ \\
\hline DC-54B & Bege claro & Bege claro & Bege claro \\
\hline BC-03D & Bege claro & Bege claro & $\begin{array}{c}\text { Bege } \\
\text { amarelado }\end{array}$ \\
\hline BC-06D & Bege escuro & $\begin{array}{c}\text { Marrom } \\
\text { escuro }\end{array}$ & $\begin{array}{c}\text { Marrom } \\
\text { escuro }\end{array}$ \\
\hline BC-14 & Bege & $\begin{array}{c}\text { Marrom claro } \\
\text { avermelhado }\end{array}$ & $\begin{array}{c}\text { Marrom } \\
\text { avermelhado }\end{array}$ \\
\hline
\end{tabular}

A amostra BC-14 apresentou cores de queima relativamente mais avermelhadas e mais escuras que as anteriores, principalmente nas temperaturas mais elevadas.

\section{POSSÍVEIS APLICAÇÕES DOS SEDIMENTOS} ARGILOSOS ANALISADOS A indústria de cerâmica branca emprega massas constituídas principalmente por argilas cauliníticas e materiais fundentes (feldspatos, calcita, dolomita e outros). Assim, os materiais devem apresentar elevada plasticidade, cores claras após a queima, ampla variação nos valores de absorção de água e porosidade aparente, alta resistência mecânica após secagem a $110^{\circ}(0,5 \mathrm{MPa})$ e, quando sinterizados acima de $1200^{\circ} \mathrm{C}$, o módulo de resistência à flexão deve ultrapassar 42,7 MPa (Godoy 2003).

Para a aplicação em refratários as características são similares às do material destinado à cerâmica branca. A matéria prima também deve ser rica em argilas cauliníticas com grande quantidade de alumina e baixos teores de fundentes, podendo, contudo, variar sua coloração após sinterização desde que não ocorra alteração na forma do corpo de prova em temperaturas próximas a $1400{ }^{\circ} \mathrm{C}$.

Considerando os baixos valores de densidade aparente, os altos valores de porosidade aparente e de absorção de água, a baixa quantidade de óxidos fundentes, assim como cores de queima em tons claros e não avermelhados, encontrados em temperaturas até 1200 ${ }^{\circ} \mathrm{C}$ para a amostra DC-54A, é possível inferir que esta amostra suportaria temperaturas de queimas superiores, podendo mesmo chegar a ter comportamento refratário. Entretanto, neste trabalho não foram realizados ensaios a temperaturas próximas a $1400{ }^{\circ} \mathrm{C}$.

A cerâmica vermelha é conhecida também como cerâmica estrutural. A cor avermelhada ou escura é resultante da oxidação de compostos de ferro presentes na argila. Este segmento da indústria cerâmica é um dos mais diversificados, as especificações variam conforme o produto industrial a ser fabricado: a) argilas para a fabricação de tijolos: fácil moldagem, valor médio a elevado para resistência à flexão (em torno de 2,0 MPa), cor vermelha após queima a $950{ }^{\circ} \mathrm{C}$ e máxima absorção de água de $25 \%$;

b) argilas para a fabricação de telhas: fácil moldagem, resistência à flexão elevada (acima de 6,4 MPa) e baixa absorção de água (até $20 \%$ ), cor vermelha após queima a $950{ }^{\circ} \mathrm{C}$;

c) argilas para a fabricação de pisos: argilas plásticas de fácil moldagem, elevados teores de ferro e metais que vitrificam a baixas temperaturas, a coloração desejada é vermelho-vivo, sem manchas, a partir de $1.100{ }^{\circ} \mathrm{C}$ o MRF deve ser de no mínimo $8,3 \mathrm{MPa}$ e a absorção de água inferior a 12\% (Berg 1970 apud Godoy 2003)

A presença de calcita e dolomita nas argilas faz com que seja necessária a sua moagem antes de utilizá-la no processamento de cerâmica vermelha, pois esses minerais hidratam-se na presença de umidade, aumentando o volume e produzindo lascamentos na superfície das peças.

Considerando-se esses critérios, pode-se avaliar que os sedimentos argilosos analisados têm aplicações conforme apresentado na tabela 6 .

Tabela 6 - Prováveis aplicações cerâmicas das amostras estudadas de sedimentos argilosos da Depressão do Piraí e da Bacia de Curitiba (baseado em Godoy 2003).

\begin{tabular}{c|c|c|c|c}
\hline \multirow{2}{*}{ Amostras } & \multicolumn{4}{|c}{ Diferentes usos na indústria cerâmica } \\
\cline { 2 - 5 } & \multirow{2}{*}{ Branca } & \multicolumn{3}{|c}{ Vermelha } \\
\cline { 3 - 5 } & & Tijolos & Telhas & Pisos \\
\hline DC-52A & & $\mathrm{xxxx}$ & & \\
\hline DC-54A & & $\mathrm{xxxx}$ & & \\
\hline DC-54B & & $\mathrm{xxxx}$ & & \\
\hline BC-03D & & $\mathrm{xxxx} *$ & & \\
\hline BC-06D & & $\mathrm{xxxx}$ & & $\mathrm{xxxx}$ \\
\hline BC-14 & & $\mathrm{xxxx}$ & & $\mathrm{xxxx}$ \\
\hline * devido à presença de calcita e dolomita, deve ser moída previamente
\end{tabular}

*devido à presença de calcita e dolomita, deve ser moída previamente

CONCLUSÕES A Depressão do Piraí e a Bacia de Curitiba são duas áreas de ocorrência de sedimentos argilosos, acumulados e parcialmente preservados graças a desnivelamentos e basculamentos de blocos de falhas. A evolução destas duas bacias tem sido relacionada aos mesmos processos geradores do Sistema de Riftes Cenozóicos do Sudeste do Brasil (SRCSB). Os estudos realizados envolveram a caracterização química, mineralógica e tecnológica de sedimentos argilosos presentes nas duas áreas.

Os sedimentos analisados são principalmente lamas de origem gravitacional (fluxos densos) e argilas 
de suspensão (transbordamento, fluxos densos subaquosos). As análises mineralógicas indicaram presença principalmente de caulinita detrítica e diagenética nos depósitos da Depressão do Piraí, caulinita detrítica e diagenética, ilita e argilas esmectíticas diagenéticas na Bacia de Curitiba. Estes resultados sugerem, por analogia, que os depósitos analisados da Bacia de Curitiba sejam correlacionáveis à fase paleogênica do desenvolvimento do SRCSB, enquanto que os depósitos da Depressão do Piraí corresponderiam a fases mais novas.

$\mathrm{Na}$ Bacia de Curitiba os sedimentos apresentam calcita, dolomita e outros carbonatos mais complexos, refletindo influência das áreas-fontes, principalmente a Formação Capiru do Grupo Açungui, na borda norte da bacia. A presença destes carbonatos influencia fortemente as características tecnológicas do material. Os sedimentos também mostram ilitização da borda de cristais de argilas esmectíticas por processos diagenéticos.

Os ensaios tecnológicos realizados indicam a possibilidade de utilização dos sedimentos argilo- sos nas indústrias cerâmicas, sendo que as amostras da Depressão do Piraí podem apenas ser utilizadas na fabricação de tijolos enquanto que os sedimentos argilosos da Bacia de Curitiba (BC-06 e BC-14) podem ser utilizados na indústria de cerâmica vermelha para fabricação de tijolos e pisos.

Agradecimentos Ao CNPq, financiador da bolsa de Produtividade em Pesquisa de M.S. Melo e L.A. Fernandes e de Iniciação Científica de T.F.S. Melo, à Fundação Araucária, financiadora do Projeto de Pesquisa, ao Geógrafo Fábio Macedo de Lima (doutorando na UFPR), à Geóloga Ana Maria Góes (IG-USP), aos geólogos Edimar Perico, Camile Urban e Denise Alessandra Monteiro Machado (alunos da UFPR), que participaram de etapas dos trabalhos de campo e da coleta das amostras analisadas. Ao Químico José Eduardo Ferreira da Costa Gardolinski (UFPR) que realizou as análises termodiferenciais e termogravimétricas.

\section{Referências}

Almeida F.F.M. 1952. Novas ocorrências de camadas supostas pliocênicas nos estados de São Paulo e Paraná. Boletim da Sociedade Brasileira de Geologia, 1(1):53-58.

Almeida F.F.M. 1976. The System of Continental Rifts Bordering the Santos Basin, Brazil. An. Acad. brasil. Ciênc., 48(Supl.):15-26.

Becker R.D. 1982. Distribuição dos sedimentos cenozóicos na região metropolitana de Curitiba e sua relação com a estrutura geológica e morfológica regional. Tese de Doutoramento, Depart. de Geociências, UFRGS, 237 p.

Bigarella J.J. \& Salamuni R. 1962. Caracteres texturais dos sedimentos da Bacia de Curitiba. Boletim da Universidade do Paraná, 7:1-164,

Coimbra A.M., Riccomini C., Sant'Anna L.G., Valarelli J.V. 1996. Bacia de Curitiba: estratigrafia e correlações regionais. In: SBG, Congr. Bras. Geol., 39, Salvador, 1996. Anais, Salvador, 1:135-137.

Coutinho J.M.V. 1955. Geologia e petrologia da região de Piraí do Sul, Paraná. Boletim da Sociedade Brasileira de Geologia, 4(1):49-65.

Godoy L.C. 2003. Caracterização tecnológica de materiais argilosos primários da região de Carambeí, estado do Paraná. 2003. Dissertação de Mestrado, Engenharia e Ciência de Materiais, Universidade Estadual de Ponta Grossa, 176 p.

Lima F.M. \& Melo M.S. 2005. Gênese dos depósitos cenozóicos da região de Castro e Piraí do Sul, PR - a depressão do Piraí. In: UEPG, Encontro de Pesquisa da UEPG, 5, Anais (CD-Rom).

Melo M.S., Riccomini C., Hasui, Y., Almeida, F.F.M., Coimbra, A.M. 1985. Geologia e evolução do Sistema de Bacias Tafrogênicas Continentais do Sudeste do Brasil. Rev. Bras. Geoc, 15(3):193-201.

MINERAIS DO PARANÁ S/A. (MINEROPAR) 2001. Atlas geológico do Estado do Paraná. Curitiba, Mineropar, $116 \mathrm{p}$.
MINERAIS DO PARANÁ S/A. (MINEROPAR) 2005a. Mapa geológico do Estado do Paraná, Folha Telêmaco Borba. Curitiba, mapa geológico, escala 1:250.000.

MINERAIS DO PARANÁ S/A. (MINEROPAR) 2005b. Mapa geológico do Estado do Paraná, Folha Curitiba. Curitiba, mapa geológico, escala 1:250.000.

MINERAIS DO PARANÁ S/A. (MINEROPAR) 2005c. Mapa geológico do Estado do Paraná, Folha Ponta Grossa. Curitiba, mapa geológico, escala 1:250.000.

Riccomini C. 1989. O Rift Continental do Sudeste do Brasil. Tese de Doutoramento, Inst. Geociências da USP, 256 p.

Riccomini C., Sant'Anna L.G., Ferrari A.L. 2004. Evolução geológica do rift continental do sudeste do Brasil. In: Mantesso-Neto V., Bartorelli A., Carneiro C.D.R., BritoNeves B.B. (orgs.) Geologia do Continente Sul-Americano: evolução da obra de Fernando Flávio Marques de Almeida. São Paulo:Beca, p. 383-405.

Salamuni E. 1989. Tectônica da Bacia Sedimentar de Curitiba. Tese de Doutoramento, Instituto de Geociências e Ciências Exatas, Universidade Estadual Paulista, Rio Claro, $211 \mathrm{p}$.

Salamuni E., Ebert H., Hasui Y. 2004. Morfotectônica da bacia sedimentar de Curitiba. Rev. Bras. Geoc. 34(4):469478.

Santos P.S. 1989. Ciência e Tecnologia de Argilas. São Paulo, Editora Edgard Blücher, 408 p.

Welton J.E. 1984. SEM petrology atlas. The Americam Association of Petroleum Geologists (Methods in exploration series), Oklahoma, Tulsa, 237 p.

Zalán P.V. \& Oliveira J.A.B. 2005. Origem e evolução estrutural do Sistema de Riftes Cenozóicos do Sudeste do Brasil. R.Janeiro, Bol. Geoci. Petrobrás, 13(2):269-300.

Manuscrito ID 14627

Submetido em 22 de novembro de 2009 Aceito em 05 de março de 2010 